\title{
Proof of Concept of an Iron-Iron(III)oxide hydroxide Battery Working at Neutral pH
}

\author{
C. Gutsche*, S. Berling, T. Plaggenborg, J. Parisi, M. Knipper
}

University of Oldenburg, Department of Physics, Energy and Semiconductor Research Laboratory, Carl-von-Ossietzky Str. 9-11, 26129 Oldenburg, Germany

*E-mail: Christian.gutsche@ uni-oldenburg.de

doi: $10.20964 / 2019.02 .37$

Received: 12 February 2018 / Accepted: 8 November 2018 / Published: 5 January 2019

An iron-iron(III)oxide hydroxide battery working in a neutral $\mathrm{pH}$ range is introduced. It employs electrochemical deposition of metallic $\mathrm{Fe}$ at the negative electrode and $\mathrm{Fe}^{\mathrm{III}} \mathrm{OOH}$ at the positive electrode during charge and dissolution of both during discharge in an aqueous $\mathrm{Fe}^{\mathrm{II}}$ electrolyte. The working principle was validated with cyclic voltammetry, charge-discharge cycles, weighing, profilometry, X-ray diffraction, scanning electron microscopy, and energy dispersive X-ray analysis. The coulombic efficiency over seven cycles is $(49 \pm 5) \%$, while it is $(40 \pm 2) \%$ for the voltaic efficiency and $(20 \pm 1) \%$ for the overall efficiency using current densities for charging and discharging of $1.2 \mathrm{~mA} \mathrm{~cm}^{-2}$ and $0.4 \mathrm{~mA} \mathrm{~cm}{ }^{-2}$ at the negative electrode and $24 \mu \mathrm{A} \mathrm{cm}^{-2}$ and $8 \mu \mathrm{A} \mathrm{cm}$ at the positive electrode. .

Keywords: Lepidocrocite; Low-cost battery; Neutral electrolyte; Fe ${ }^{\mathrm{II}}$; FeOOH

\section{$\underline{\text { FULL TEXT }}$}

(C) 2019 The Authors. Published by ESG (www.electrochemsci.org). This article is an open access article distributed under the terms and conditions of the Creative Commons Attribution license (http://creativecommons.org/licenses/by/4.0/). 